\title{
SHORT-TIMESCALE VARIATION OF PHYTOPLANKTON ABUNDANCE AND DIVERSITY AT REDANG ISLAND
}

\author{
Joon Hai Lim¹, Choon Weng Lee ${ }^{1,2, *}$ \\ ${ }^{1}$ Laboratory of Microbial Ecology, Institute of Biological Sciences, University of Malaya, 50603 Kuala Lum- \\ pur, Malaysia \\ ${ }^{2}$ Institute of Ocean and Earth Sciences, University of Malaya, 50603 Kuala Lumpur, Malaysia \\ *Corresponding author: lee@um.edu.my
}

\begin{abstract}
A short-timescale sampling of phytoplankton abundance and diversity was carried out at Redang Island waters, South China Sea. Physico-chemical variables measured at four intervals over a day were relatively stable (temperature $=29 \pm 0.6^{\circ} \mathrm{C}$; salinity $=27 \pm 2 \mathrm{ppt}, \mathrm{pH}=7.8 \pm 0.1$; total alkalinity $=2025 \pm 33 \mu \mathrm{eq} \mathrm{1}^{-1}$ ) whereas inorganic nutrient concentrations $\left(\mathrm{NH}_{4}=1.36 \pm 0.51 \mu \mathrm{M} ; \mathrm{NO}_{2}=0.06 \pm 0.03 \mu \mathrm{M} ; \mathrm{PO}_{4}=0.08 \pm 0.03 \mu \mathrm{M}\right.$; and $\mathrm{SiO}_{4}=9.98 \pm 0.54 \mu \mathrm{M}$ ) were low and reflected oligotrophic conditions. The oligotrophic nature of Redang Island waters supported relatively lower biomass i.e. bacterial abundance $=6.6 \pm 0.5 \times 10^{5} \mathrm{cell} \mathrm{ml}^{-1}$; picoplankton abundance $=9.3 \pm 0.8 \times 10^{4} \mathrm{cell} \mathrm{ml}^{-1}$; phytoplankton abundance $=4.8 \pm 2.2 \times 10^{3} \mathrm{cell} \mathrm{ml}^{-1}$ and zooplankton

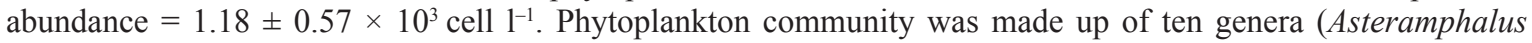
sp., Bacteriastrum sp., Chaetoceros sp., Cosinodiscus sp., Diploneis sp., Hemialus sp., Leptocylindricus sp., Navicula sp., Nitzschia sp., and Rhizosolenia sp.), and significantly different from near-shore waters. Redang Island waters exhibited a simpler phytoplankton community which is probably more susceptible to climate change.
\end{abstract}

\begin{abstract}
ABSTRAK Penyampelan cara skala masa pendek mengkaji kelimpahan dan kepelbagaian fitoplankton telah dijalankan di perairan Pulau Redang, Laut China Selatan. Pembolehubah fiziko-kimia yang diukur empat kali dalam sehari adalah agak stabil (suhu $=29 \pm 0.6^{\circ} \mathrm{C}$; kemasinan $=27 \pm 2 \mathrm{ppt}, \mathrm{pH}=7.8 \pm 0.1$; jumlah kealkalian $=$ $\left.2025 \pm 33 \mu \mathrm{eq} \mathrm{l}^{-1}\right)$ manakala kepekatan nutrien tak organik $\left(\mathrm{NH}_{4}=1.36 \pm 0.51 \mu \mathrm{M} ; \mathrm{NO}_{2}=0.06 \pm 0.03 \mu \mathrm{M} ; \mathrm{PO}_{4}=\right.$ $0.08 \pm 0.03 \mathrm{pM}$; dan $\mathrm{SiO}_{4}=9.98 \pm 0.54 \mu \mathrm{M}$ ) adalah rendah dan mencerminkan keadaan oligotrofik. Sifat oligotrofik perairan Pulau Redang pula menyokong biojisim yang rendah iaitu kelimpahan bakteria $=6.6 \pm 0.5 \times 10^{5} \mathrm{sel} \mathrm{ml}^{-1}$; kelimpahan pikoplankton $=9.3 \pm 0.8 \times 10^{4} \mathrm{sel} \mathrm{ml}^{-1}$; kelimpahan fitoplankton $=4.8 \pm 2.2 \times 10^{3} \mathrm{sel} \mathrm{ml}^{-1}$ dan $\mathrm{kelimpahan}$ zooplankton $=1.18 \pm 0.57 \times 10^{3} \mathrm{sel} l^{-1}$. Komuniti fitoplankton terdiri daripada sepuluh genus (Asteramphalus sp., Bacteriastrum sp., Chaetoceros sp., Cosinodiscus sp., Diploneis sp., Hemialus sp., Leptocylindricus sp., Navicula sp., Nitzschia sp., dan Rhizosolenia sp.), dan secara bererti berbeza dari perairan dekat pantai. Perairan Pulau Redang mempamerkan komuniti fitoplankton yang lebih ringkas, dan yang lebih mudah dipengaruhi oleh perubahan iklim.
\end{abstract}

(Keywords: coral reef, Redang Island, phytoplankton abundance, phytoplankton diversity, Sunda Shelf)

\section{INTRODUCTION}

Phytoplankton plays an important role functioning at the base of the food web through photosynthesis, incorporating dissolved carbon dioxide (CO2) as biomass $[5,23]$. In recent years, anthropogenic activities have greatly affected the global carbon $(\mathrm{C})$ cycle where an increasing amount of $\mathrm{CO} 2$ being released into the atmosphere is identified as the main cause of global warming $[9,11]$. This has accelerated research on ocean primary producers (e.g. phytoplankton) as primary production is responsible for removing 30 $-60 \%$ of the CO2 emissions [5,17]. Phytoplankton is usually classified as $>2 \mu \mathrm{m}$ fraction, and consists mainly of diatoms and dinoflagellates [18]. Variability in phytoplankton biomass is attributed to light intensity, seawater temperature and inorganic nutrient concentrations $[3,26,30]$ whereas phytoplankton diversity reflects the resilience of the phytoplankton community to environmental stresses $[12,28]$.

The Sunda Shelf region is important in terms of marine biodiversity and yet studies on phytoplankton in this region have mainly focused on near-shore coastal waters e.g. Klang and Port Dickson [13]. This present study was an attempt to complement our understanding of phytoplankton distribution by studying waters with less anthropogenic influence. We chose Redang Island waters located on the east side of Peninsular Malaysia. Redang Island is a popular tourist spot with teeming coral reefs. As phytoplankton exhibits relatively short reaction time to environmental change, we adopted a short-timescale sampling strategy to observe for any temporal variation. Although we only captured 'snapshots' of the environment in this study, short-term changes can 
drive long-term patterns [29], and results from this study could give us a lead on possible long-term research strategies.

\section{MATERIALS AND METHODS}

\section{Sampling and Physiochemical Characteristics}

Short-timescale sampling was carried out at Redang Island (N5'46', E103'02'), east coast of Malaysia (Figure 1). Four samplings were carried out over a one-day period (8:00 am, 11:00 am, 14:30 pm and $17: 30 \mathrm{pm}$ ), and about 121 of water sample was collected each time. Physical parameters such as temperature, salinity (YSI-30, USA) and pH (Mi 106, USA) were measured in-situ. For inorganic nutrient analyses [ammonium (NH4), phosphate (PO4), nitrite (NO2) and silicate (SiO4)] [19] and total alkalinity measurements [7], seawater sample was preserved with mercury chloride $(\mathrm{HgCl} 2)(1 \%$ final concentration). Although nitrate (NO3) predominates in island or offshore waters in this region [13], it was not measured here as the preservation method was not suitable for NO3 analysis [8]. Additionally, $10 \mathrm{ml}$ of the seawater sample was preserved with glutaraldehyde ( $4 \%$ final concentration) for bacteria and phototrophic picoplankton enumeration. The remaining water sample $(\approx 5.51)$ was concentrated via plankton nets with mesh sizes of $140 \mu \mathrm{m}$ and 20 $\mu \mathrm{m}$ for zooplankton and phytoplankton, respectively. These samples were then preserved with $4 \% \mathrm{Lu}-$ gol's iodine [27]. All preserved samples were kept cold until further analyses in the laboratory.

\section{Plankton Enumeration}

Bacterial abundance was determined via epifluorescence microscopy (Olympus BX60, Japan) on samples stained with 4',6-diamidino-2-phenylindole (DAPI) [21] whereas unstained samples were viewed for autofluorescing phototrophic picoplankton (Ppico). For phytoplankton and zooplankton enumeration, samples were placed in a sedimentation chamber and observed via an inverted microscope (Olympus IX51, Japan) whereas phytoplankton identification was carried out according to Salleh \& Tajuddin [24].

\section{Statistical Analyses}

All values were reported as mean \pm standard deviation (S.D.) unless otherwise stated. Shannon-Wiener diversity index (H') [25] was used to express phytoplankton species richness in the community, taking into account the proportion of each genus relative to their abundance whereas correlation analysis was used to show the relationship among the different parameters measured. Comparison of the phytoplankton community was carried out via Analysis of Similarity (ANOSIM). All tests were carried out with the software PAST [10].

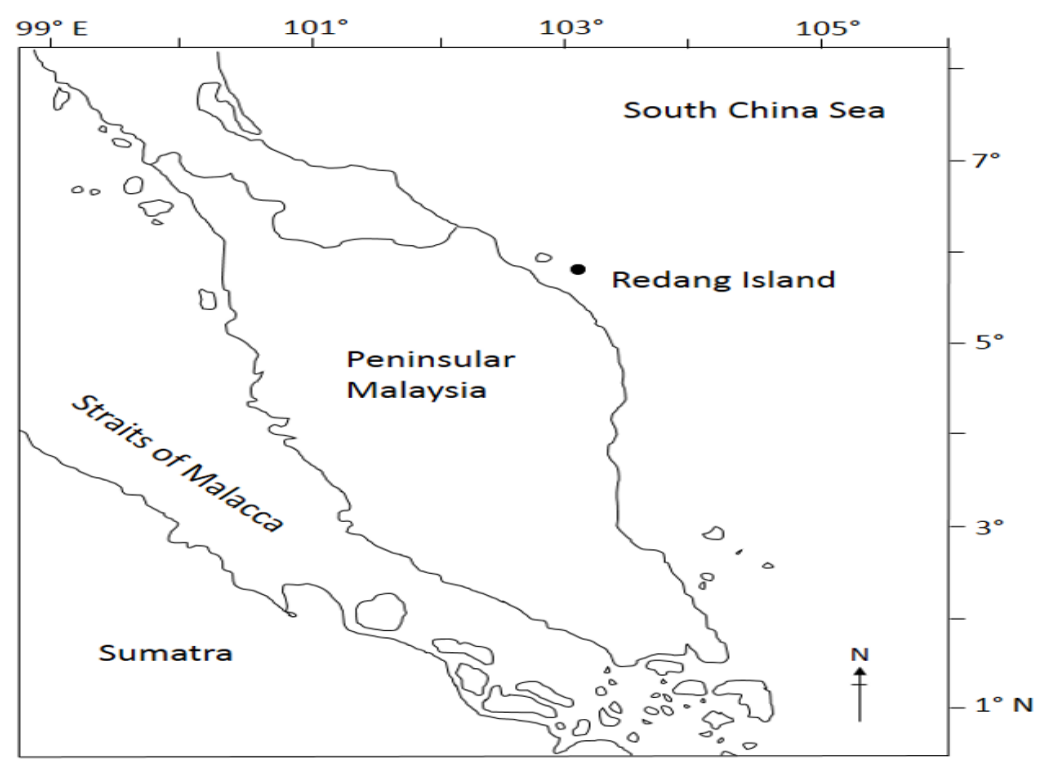

Figure 1. Location of Redang Island sampling site (N 5 $46^{\prime}$, E $103^{\circ} 02^{\prime}$ ). 


\section{RESULTS}

Seawater temperature measured varied within a narrow range throughout the day, from 28 to $29^{\circ} \mathrm{C}$ $\left(29 \pm 0.6^{\circ} \mathrm{C}\right)$ whereas salinity varied from 25 to 28 ppt $(27 \pm 2$ ppt) (Figure 2). There was also minimal change in $\mathrm{pH}$ i.e. from 7.8 to $7.9(7.8 \pm$ $0.1)$ throughout the day. Similarly, total alkalinity ranged from 1990 to $2060 \mu \mathrm{eq} 1^{-1}(2025 \pm 33 \mu \mathrm{eq}$ $\mathrm{1}^{-1}$ ). As for inorganic nutrient concentrations, $\mathrm{NH}_{4}$ and $\mathrm{NO}_{2}$ fluctuated from 0.92 to $2.06 \mu \mathrm{M}(1.36 \pm$ $0.51 \mu \mathrm{M})$ and 0.02 to $0.09 \mu \mathrm{M}(0.06 \pm 0.03 \mu \mathrm{M})$, respectively. On the other hand, $\mathrm{PO}_{4}$ and $\mathrm{SiO}_{4}$ fluctuated from 0.04 to $0.10 \mu \mathrm{M}(0.08 \pm 0.03 \mu \mathrm{M})$ and 9.20 to $10.33 \mu \mathrm{M}(9.98 \pm 0.54 \mu \mathrm{M})$, respectively.

In terms of the biology, bacterial abundance varied from 5.8 to $7.2 \times 10^{5}$ cell ml $^{-1}\left(6.6 \pm 0.5 \times 10^{5}\right.$ cell $\mathrm{ml}^{-1}$ ) whereas Ppico abundance was about twoorders of magnitude lower, from 0.8 to $1.0 \times 10^{4}$ cell ml ${ }^{-1}\left(9.3 \pm 0.8 \times 10^{4}\right.$ cell ml$\left.^{-1}\right)$. Both bacterial and Ppico abundance were relatively stable
(Coefficient of Variation, $\mathrm{CV}=13 \%$ ). In contrast, phytoplankton and zooplankton abundance varied over two-fold. Phytoplankton abundance fluctuated from 2.6 to $7.7 \times 10^{3}$ cell ml ${ }^{-1}$ (4.8 $\pm 2.2 \times 10^{3} \mathrm{cell} \mathrm{ml}^{-1}$ ) (Figure 2) and the genera observed were Asteramphalus sp., Bacteriastrum sp., Chaetoceros sp., Cosinodiscus sp., Diploneis sp., Hemialus sp., Leptocylindricus sp., Navicula sp., Nitzschia sp., and Rhizosolenia sp. (Figure $3)$. The predominant genus observed here was Chaetoceros sp. which accounted for $>58 \%$ of the phytoplankton abundance. Phytoplankton diversity in terms of Shannon-Wiener diversity index $\left(\mathrm{H}^{\prime}\right)$ ranged from 0.439 to $1.076(0.822$ \pm 0.303). Zooplankton abundance fluctuated in tandem with phytoplankton abundance and varied more than two-fold from 0.54 to 1.82 $\times 10^{3}$ cell $\mathrm{1}^{-1}\left(1.18 \pm 0.57 \times 10^{3}\right.$ cell $\left.\mathrm{1}^{-1}\right)$. Both phytoplankton and zooplankton abundance were highest at around noon (11:00 am).
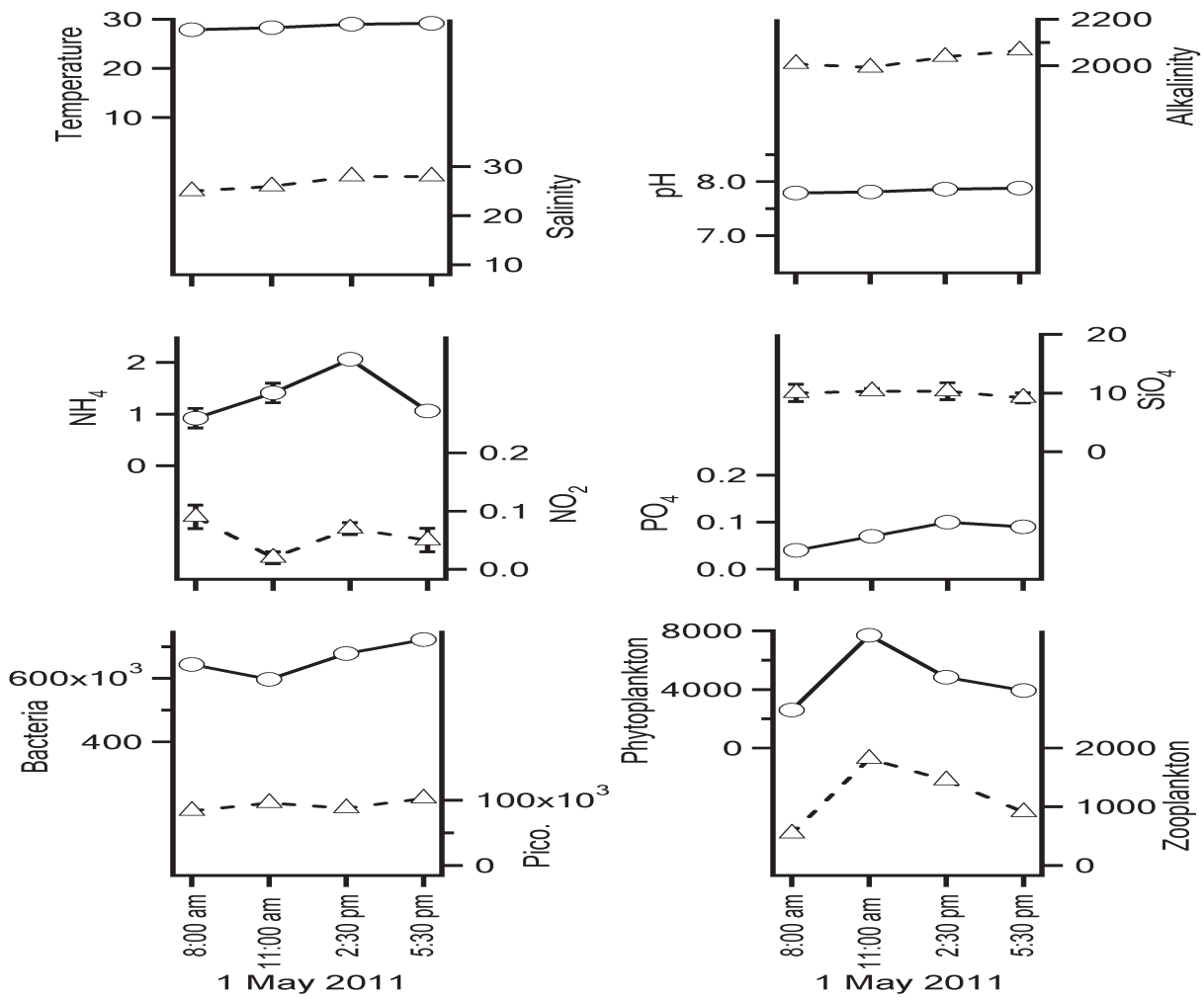

Figure 2. Short-timescale variation of temperature $\left({ }^{\circ} \mathrm{C}\right)$, salinity $(\mathrm{ppt}), \mathrm{pH}$, alkalinity $\left(\mu \mathrm{eq} \mathrm{1}^{-1}\right)$, ammonium $(\mathrm{NH} 4, \mu \mathrm{M})$, nitrite $(\mathrm{NO} 2, \mu \mathrm{M})$, phosphate $(\mathrm{PO} 4, \mu \mathrm{M})$, silicate $(\mathrm{SiO} 4, \mu \mathrm{M})$, bacterial abundance $\left(\right.$ cell $\left.\mathrm{ml}^{-1}\right)$, phototrophic picoplankton abundance $\left(\right.$ Pico., cell $\mathrm{ml}^{-1}$ ), phytoplankton abundance $\left(\right.$ cell $\left.\mathrm{ml}^{-1}\right)$ and zooplankton abundance (cell $\mathrm{l}^{-1}$ ) measured at Redang Island. 


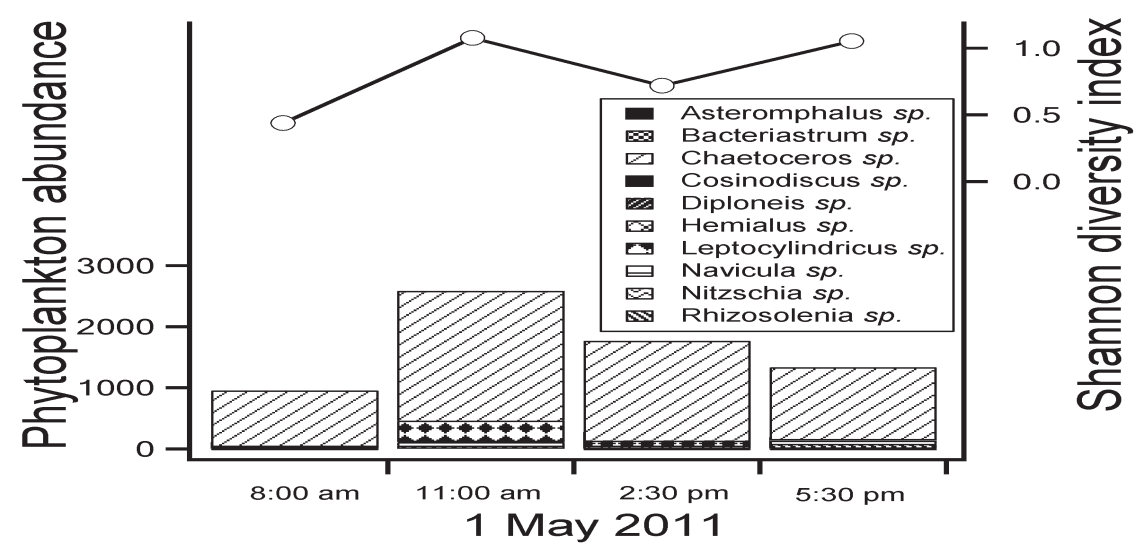

Figure 3. Composition of different phytoplankton based on abundance (cell $\mathrm{ml}^{-1}$ ) and Shannon diversity index $\left(\mathrm{H}^{\prime}\right)$ observed at each interval.

\section{DISCUSSION}

Generally, the temperature observed at Redang Island is typical of tropical waters [13]. Average salinity and $\mathrm{pH}$ were relatively constant probably because there was no significant freshwater input at Redang Island. Total alkalinity was reported for the first time for coral reef waters in Malaysia, and was within the range measured at other coral reef systems e.g. Great Barrier Reef [2]. In general, inorganic nutrient concentrations (NH4, NO2, PO4, and $\mathrm{SiO} 4)$ at Redang Island were low and reflected an oligotrophic state. This is typical of coral reef systems that are characterized by low nutrient inputs [16].

The oligotrophic nature of the Redang Island waters supported a strikingly lower amount of biomass compared to other coastal water systems in this region $[13,14]$. Both bacterial and Ppico abundance at Redang Island were about one order lower than near-shore coastal waters $[13,15]$. Ppico abundance in Redang Island waters also correlated significantly to phytoplankton abundance $(\mathrm{R}=0.87, \mathrm{p}<0.05)$. This is in contrast to near-shore waters where Ppico abundance was independent of phytoplankton abundance (unpublished data). Our observations concurred with others who reported the co-dominance of Ppico and phytoplankton as typical in oligotrophic waters $[1,22]$ due to the nutrient uptake efficiency of Ppico with their high surface-to-volume ratio [22].

In this study, phytoplankton abundance varied over two-fold, and peaked at around noon. This temporal pattern is probably the result from increased phytoplankton growth with day-light. From the phytoplankton community profile, we observed the predominance of Chaetoceros sp. in Redang Island waters throughout the day. Chaetoceros sp. employs the r-strategy, is small in size and could respond to the nutrient limiting conditions [20]. Chaetoceros sp. also correlated with zooplankton abundance (R $=0.93, \mathrm{p}<0.01)$. Although we did not measure zooplankton grazing rate, zooplankton grazing is an important process that accounts for $60-75 \%$ of daily phytoplankton production $[4,6]$, and the correlation between zooplankton abundance and Chaetoceros sp. that we observed could be a result of predator-prey coupling.

In order to place our study here within a larger spatial context, we compared our study here with data from Port Dickson and Klang estuary (unpublished data), representing mesotrophic and eutrophic systems, respectively. Generally, phytoplankton abundance at Redang Island was similar to Port Dickson (9.85 $\pm 0.15 \times 10^{3} \mathrm{cell} \mathrm{ml}^{-1}$ ) but lower compared to Klang $\left(1.39 \pm 0.99 \times 10^{4} \mathrm{cell} \mathrm{m}^{-1}\right)$. Eutrophic systems have higher amounts of nutrients that support a higher phytoplankton biomass [13]. However in terms of phytoplankton community, we observed that the phytoplankton community from these three stations were significantly different (ANOSIM: $R=0.85$, $P<0.001)$. The lower phytoplankton abundance and oligotrophic nature at Redang Island resulted in a simpler phytoplankton community (with 10 genera) compared to Klang (28 genera) and Port Dickson (28 genera). One of the perils of small phytoplankton community is the susceptibility to climate change due to the decreased variety of response from the community [12,28]. 


\section{CONCLUSION}

From this study, we reported the phytoplankton community from Redang Island waters which also represented coral reef waters. The oligotrophic nature of these waters supported a lower phytoplankton abundance and a simpler phytoplankton community, suggesting the susceptibility of these communities to climate change.

\section{ACKNOWLEDGEMENTS}

We are grateful to University of Malaya for the grants (UM.C/625/1/HIR/050, RU006D-2014 and PV060/2011B) that supported this work. We also thank the Ministry of Science, Technology and Innovation for the eScience grant (04-01-03-SF0671) and the Ministry of Education for the HiCoE grant (IOES-2014D).

\section{REFERENCES}

1. Agawin, N.S.R., Duarte, C.M., \& Agustí, S. (2000). Nutrient and temperature control of the contribution of picoplankton to phytoplankton biomass and production. Limnology and Oceanography 45, 591-600.

2. Albright, R., Langdon, C., \& Anthony, K.R.N. (2013). Dynamics of seawater carbonate chemistry, production, and calcification of a coral reef flat, central Great Barrier Reef. Biogeosciences 10, 6747-6758.

3. Arin, L., Morán, X.A.G., \& Estrada, M. (2002). Phytoplankton size distribution and growth rates in the Alboran Sea (SW Mediterranean): short term variability related to mesoscale hydrodynamics. Journal Plankton Research 24, 1019-1033.

4. Calbet, A., \& Landry, M.R. (2004). Phytoplankton growth, microzooplankton grazing, and carbon cycling in marine systems. Limnology and Oceanography 49(1), 51-57.

5. Falkowski, P., Scholes, R.J., Boyle, E., Canadell, J., Canfield, D., Elser, J., Gruber, N., Hibbard, K., Höegberg, P., Linder, S., Mackenzie, F.T., Moore III, B., Pedersen, T., Rosenthal, Y., Seitzinger, S., Smetacek, V., \& Steffen, W. (2000). The global carbon cycle: a test of our knowledge of earth as a system. Science 290, 291-296.
6. Goldyn, R., \& Kowalczewska-Madura, K. (2008). Interactions between phytoplankton and zooplankton in the hypertrophic Swarzedzkie Lake in western Poland. Journal Plankton Research 30(1), 33-42.

7. Gran, G. (1950). Determination of the equivalence point in potentiometric titrations. Acta Chemica Scandinavica 4, 559-577.

8. Grasshoff, K., Kremling, K., \& Ehrhardt, M. (1999). Methods of Seawater Analysis, 3rd edn. Weinheim: Wiley-VCH.

9. Gregg, W.W., Conkright, M.E., Ginoux, P., O'Reilly, J.E., \& Casey, N.W. (2003). Ocean primary production and climate: global decadal changes. Geophysical Research Letters 30,15.

10. Hammer, Ø., Harper, D.A.T., \& Ryan, P.D. (2001). PAST: Paleontological Statistics Software Package for Education and Data Analysis. Palaeontologia Electronica 4(1), 1-9.

11. IPCC (Intergovernmental Panel on Climate Change). (2007). Climate change: the physical science basis. Contribution of Working Group I to the 4th Assessment Report of the Intergovernmental Panel on Climate change. Cambridge, Cambridge University Press.

12. Ives, A.R., Gross, K., \& Klug, J.L. (2000). Stability and variability in competitive communities. Science 286, 542-544.

13. Lee, C.W., \& Bong, C.W. (2008). Bacterial abundance and production and their relation to primary production in tropical coastal waters of Peninsular Malaysia. Marine \& Freshwater Research 59, 10-21.

14. Lee, C.W., Bong, C.W., \& Hii, Y.S. (2009). Temporal variation of bacterial respiration and growth efficiency in tropical coastal waters. Applied and Environmental Microbiology 75, $7594-7601$.

15. Lee, C.W., Lim, J.H., \& Heng, P.L. (2013). Investigating the spatial distribution of phototrophic picoplankton in a tropical estuary. Environmental Monitoring and Assessment 185, 9697-9704.

16. Mohamed Che, A.R., \& Lee, J.N. (2011). Accumulation of settling particles in some coral reef areas of Peninsular Malaysia. Sains Malaysiana 40(6), 549-554. 
17. Mullineaux, C.W. (1999). The plankton and the planet. Science 283, 801-802.

18. Nyabakken, J.W. (1997). Marine biology: An ecological approach. USA: Addison-Wesley Education.

19. Parsons, T.R., Maita, Y., \& Lalli, C.M. (1984). A manual of chemical and biological methods for seawater analysis. Oxford: Pergamon Press.

20. Pianka, E.R. (1970). On $\mathrm{r}$ and $\mathrm{K}$ selection. The American Naturalist 104 (940), 592-597.

21. Porter, K.G., \& Feig, Y.S. (1980). The use of DAPI for identifying and counting aquatic microflora. Limnology and Oceanography 25, 943-948.

22. Raven, J.A. (1998). Small is beautiful: the picoplankton. Functional Ecology 12(4), 503-513.

23. Sabine, C.L., Feely, R.A., Gruber, N., Key, R.M., Lee, T., Bullister, J.L., Wanninkhof, R., Wong, C.S., Wallace, D.W.R., Tilbrook, B., Millero, F.J., Peng, T.H., Kozyr, A., Ono, T., \& Rios, A.F. (2004). The Oceanic sink for anthropogenic CO2. Science 305, 367-371.

24. Salleh, A., \& Tajuddin, Z.M. (2006). Phytoplankton of Carey Island. Kuala Lumpur: Golden Hope Plantation Berhad and Institute of Biological Sciences, University of Malaya.
25. Shannon, C.E., \& Weaver, W. (1949). The mathematical theory of communication. Urbana: The University of Illinois Press.

26. Sigman, D.M., \& Hain, M.P. (2012). The biological productivity of the ocean: Section 1 . Nature Educational Knowledge 3, 21.

27. Throndsen J. (1978). Preservation and storage. In A Sournia (Ed.), Phytoplankton Manual, (pp. 69-74). Paris: UNESCO.

28. Vasseur, D.A., \& Gaedke, U. (2007). Spectral analysis unmasks synchronous and compensatory dynamics in plankton communities. Ecology 88, 2058-2071.

29. Vaulot, D., \& Marie, D. (1999). Diel variability of photosynthetic picoplankton in the equatorial Pacific. Journal of Geophysical Research 104, 3297 - 3310 .

30. Wu, J.T., \& Chou, T.L. (2003). Silicate as the limiting nutrient for phytoplankton in a subtropical eutrophic estuary of Taiwan. Estuarine, Coastal and Shelf Science 58, 155-162. 